\title{
The Peptidoglycan Crosslinking Enzyme System in Streptomyces R61, K15 and rimosus
}

\author{
Immunological Studies
}

\begin{abstract}
Martine NGUYEN-DISTĖCHE, Jean-Marie FRÈRE, Jean DUSART, Mélina LEYH-BOUILLE, and Jean-Marie GHUYSEN
Service de Microbiologie, Faculté de Médecine, Université de Liègc
\end{abstract}

Jerry J. POLLOCK and Vincent J. IACONO

Department of Oral Biology and Pathology and Department of Periodontics, School of Dental Medicine, State University of New York at Stony Brook

(Received May 27, 1977)

The exocellular DD-carboxypeptidases from Streptomyces R61, K15, the lysozyme-releasable DD-carboxypeptidases from Streptomyces R61, K15 and rimosus, and the membrane-bound DD-carboxypeptidase of Streptomyces K15 are immunologically related to each other.

As many as four enzymes may be involved in the peptidoglycan crosslinking enzyme system in Streptomyces sp. [1]. Streptomyces K15 excretes an exocellular DD-carboxypeptidase; it has two cell-bound DD-carboxypeptidases, one of which is released by protoplasting the mycelium whereas the other is bound to the plasma membrane; and finally it possesses a transpeptidase which is also membranebound. The enzyme system in Streptomyces R61 is very similar except for the membrane-bound DD-carboxypeptidase activity which is hardly detectable. Finally, the enzyme system in Streptomyces rimosus consists almost exclusively of a membrane-bound transpeptidase. Rabbits were immunized with the purified exocellular enzyme of Streptomyces R61 and the antiserum thus obtained was used as a tool for the study of the relationship which might exist between these various enzymes. Two DD-carboxypeptidases unrelated to the preceding ones served as controls. One of them was the exocellular DD-carboxypeptidase from Actinomadura R39 [2,3]. It was selected because of the profound differences that occur in the type of interpeptide bridging in the wall peptidoglycans of the Streptomyces strains (a D-Ala-Gly-LL-diaminopimelic acid linkage) and of Actinomadura R39 (a C-terminal D-Ala-(D)-meso-diaminopimelic acid linkage) [3]. The other control enzyme was the exocellular DD-carboxypeptidase from Streptomyces albus G which, in contrast to the other Streptomyces exocellular DD-carboxypeptidases, is a cationic protein, does not perform transfer reactions, has a high lytic activity on various wall peptidoglycans and is largely insensitive to $\beta$-lactams [3].

\section{MATERIALS AND METHODS}

Enzymes

The exocellular enzymes from Streptomyces R61 and Actinomadura R39 had been purified to protein homogeneity [2]. The exocellular enzyme from Streptomyces $\mathrm{K} 15$ and the lysozyme-releasable enzymes from Streptomyces R61, K15 and rimosus were at various stages of purity as described by Leyh-Bouille et al. [1]. The cytoplasmic membranes from Streptomyces R61, K15 and rimosus were also prepared as described in [1]. The final membrane preparations contained about $25 \mathrm{mg}$ protein $/ \mathrm{ml}$ in $14 \mathrm{mM}$ phosphate buffer. Unless otherwise specified, the DD-carboxypeptidase activity was estimated by using $1.6 \mathrm{mM}$ $\mathrm{Ac}_{2}$-L-Lys-D-Ala-D-Ala and the transpeptidase activity by using $1.6 \mathrm{mM} \quad \mathrm{Ac}_{2}$-L-Lys-D-Ala-D-Ala $+1.6 \mathrm{mM}$ Gly-Gly. The techniques are those described previously [1].

\section{Radioactive Benzylpenicillin}

$\left[{ }^{14} \mathrm{C}\right]$ Benzylpenicillin (with the label in the acyl side-chain; $50 \mathrm{Ci} / \mathrm{mol}$ ) was purchased from the Radiochemical Centre (Amersham).

\section{Antiserum}

A male New Zealand white rabbit $(4-5 \mathrm{~kg})$ served as the source of antiserum. The rabbit was injected with $2 \mathrm{mg}$ R61 enzyme emulsified in $1.5 \mathrm{ml}$ $10 \mathrm{mM}$ phosphate buffer, $\mathrm{pH} 7.5$, and $1.5 \mathrm{ml}$ of com- 
plete Freund's adjuvant (Difco) into the hind foot pads, intramuscularly, and subcutaneously into the dorsum of the neck. Booster injections, each containing $1 \mathrm{mg}$ enzyme, were administered in a similar fashion at 2, 6 and 8 weeks. The rabbit was exsanguinated from the marginal ear vein 10 weeks after the first injection and the serum obtained was decomplemented at $56^{\circ} \mathrm{C}$ for $30 \mathrm{~min}$. When the enzyme preparation $(16 \mu \mathrm{g}$ and $32 \mu \mathrm{g})$ was reacted against the serum in immunodiffusion analysis [4], a single precipitation band was detected. Normal-rabbit serum obtained prior to any immunization procedures served as the control serum.

\section{RESULTS}

\section{Effects of Antiserum on the Activities of the Exocellular R61 Enzyme}

Enzyme ( $6 \mathrm{ng}$ ) and various amounts of either antiserum or control serum $(0.001-5 \mu 1)$ were incubated together in $30 \mu \mathrm{l}$, final volume, of $8 \mathrm{mM}$ Tris- $\mathrm{HCl}$ buffer $\mathrm{pH} 7.5$ for $1 \mathrm{~h}$ at $37^{\circ} \mathrm{C}$. The DD-carboxypeptidase activity was then estimated by incubating the reaction mixtures with $1.6 \mathrm{mM} \mathrm{Ac}$-L-Lys-D-Ala$\mathrm{D}$-Ala for $4 \mathrm{~h}$ at $37^{\circ} \mathrm{C}$. The control serum had no effect. Maximal inhibition of the enzyme activity by the antiserum was of $80-85 \%$ (Fig. 1). In other experiments the enzyme activity was estimated by using larger concentrations of $\mathrm{Ac}_{2}$-L-Lys-D-Ala-D-Ala up to $24 \mathrm{mM}$ (i.e. $2 \times$ the $K_{\mathrm{m}}$ value) and by decreasing accordingly the incubation times in order to maintain initial velocity measurements. The extents of enzyme inhibition effected by the various antiserum dilutions remained unchanged. Finally, the inhibition of the transpeptidase activity (as measured with 1.6 $\mathrm{mM} \mathrm{Ac}_{2}$-L-Lys-D-Ala-D-Ala $+1.6 \mathrm{mM}$ Gly-Gly) was found to parallel the inhibition of the DD-carboxypeptidase activity.

\section{Effects of Antiserum on the Penicillin-Binding Capability of the Exocellular R61 Enzyme}

Enzyme $(8.4 \mu \mathrm{g})$, various amounts of antiserum $(2-140 \mu \mathrm{l})$ and various amounts of control serum $(0-138 \mu \mathrm{l}$, with the result that all the reaction mixtures contained $140 \mu \mathrm{l}$ antiserum + control serum) were incubated together in $1040 \mu \mathrm{l}$, final volume, of $5 \mathrm{mM}$ Tris- $\mathrm{HCl}$ buffer $\mathrm{pH} 7.5$, for $1 \mathrm{~h}$ at $37^{\circ} \mathrm{C}$. The ratios of enzyme protein to antiserum were identical to those used in the preceding experiments but in the present case there was a 40 -fold increase in the absolute concentrations of the two reagents. Samples $(2 \mu \mathrm{l})$ were removed and tested for residual enzyme activity by incubating with $1.6 \mathrm{mM} \mathrm{Ac_{2 } - L - L y s - D - A l a - D - A l a ~}$

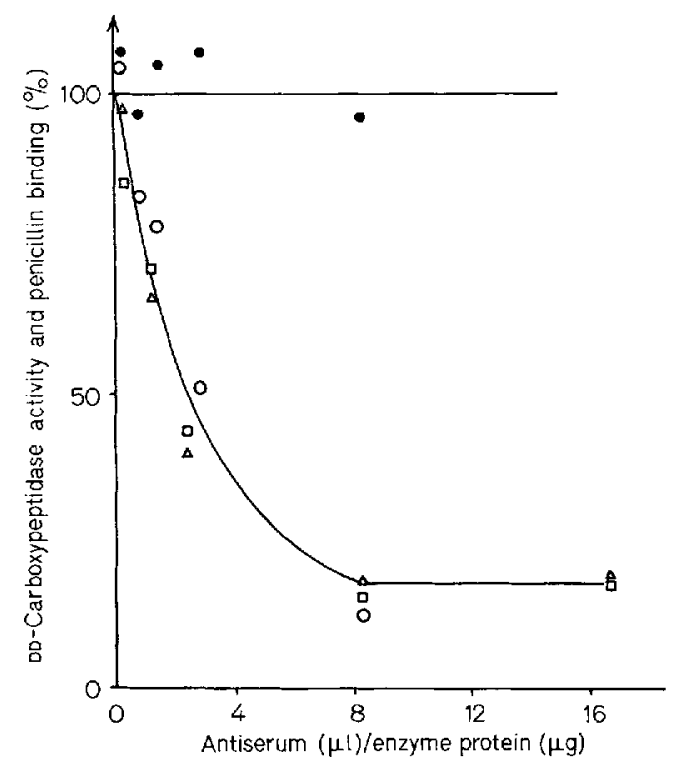

Fig.1. Effects of the antiserum to exocellular R6I enzyme on the DD-carboxypeptidase activity and penicillin-binding capability of the exocellular R6I enzyme. (-) Effect of control serum on the DD-carboxypeptidase activity; $(\mathrm{O}-\mathrm{O})$ inhibition of DD-carboxypeptidase activity under conditions where 6 ng enzyme and samples of antiserum (from 0.001 to $0.1 \mu \mathrm{l}$ ) were incubated together in $30 \mu 1$, final volume; $(\square-\square)$ inhibition of DD-carboxypeptidase activity under conditions where $8.4 \mu \mathrm{g}$ enzyme and samples of antiserum (from 2 to $140 \mu$ ) were incubated together in $1040 \mu 1$, final volume; $(\Delta-\Delta)$ effect of the antiserum on the ability to bind $\left[{ }^{14} \mathrm{C}\right]$ benzylpenicillin. For other experimental conditions, see text

in $8 \mathrm{mM}$ Tris- $\mathrm{HCl}$ buffer $\mathrm{pH} 7.5$ (final volume: $30 \mu \mathrm{l}$ ) for $90 \mathrm{~min}$ at $37^{\circ} \mathrm{C}$. All reaction mixtures were then supplemented with $0.6 \mathrm{nmol}\left[{ }^{14} \mathrm{C}\right]$ benzylpenicillin and incubated for $15 \mathrm{~min}$ at $37^{\circ} \mathrm{C}$. Trichloroacetic acid ( $5 \mathrm{ml}$ of an $11 \%$ solution) was added to each mixture at $0{ }^{\circ} \mathrm{C}$ to precipitate bound-penicillin-labelled protein. The precipitates were collected by centrifugation, washed with $8 \mathrm{ml}$ cold trichloroacetic acid solution, dried at $60^{\circ} \mathrm{C}$, solubilized with $1 \mathrm{ml}$ of Soluene and the radioactivity was counted (in $10 \mathrm{ml}$ Bray scintillation liquid). Non-specific trapping of radioactivity was estimated from solutions containing the same amounts of serum and antiserum as above but without enzyme. Fig. 1 shows that the loss of enzyme activity paralleled the loss of the ability of the enzyme to bind penicillin.

\section{Effects of Antiserum on the Activities of Enzymes Other than The Exocellular R61 Enzyme}

The same microscale technique was used to assay inhibition of other soluble (exocellular or lysozymereleasable) enzymes. The antiserum had no effect on the exocellular enzymes from both Actinomadura R39 
Table 1. Effects of the antiserum to exocellular R61 enzyme on the DD-carboxypeptidase and transpeptidase activities of the exocellular and lysozyme-releasable enzymes

The activities are expressed as percentages of the tripeptide $\mathrm{Ac}_{2}-\mathrm{L}-\mathrm{LyS}-\mathrm{D}$-Ala-D-Ala hydrolysed (DD-carboxypeptidase activity) or transformed into $\mathrm{Ac}_{2}-\mathrm{L}$-Lys-D-Ala-Gly-Gly (transpeptidase activity). All the enzyme/antiserum incubations were carried out at $37^{\circ} \mathrm{C}$ and in $30 \mu \mathrm{l}$, final volumes. The buffers used were $5-10 \mathrm{mM}$ Tris- $\mathrm{HCl}, \mathrm{pH} 7.5$, except for the exocellular enzyme from Streptomyces albus $\mathrm{G}$ ( $50 \mathrm{mM}$ Tris- $\left.\mathrm{HCl} \mathrm{pH} 8.3+5 \mathrm{mM} \mathrm{MgCl}_{2}\right)$ and for the exocellular enzyme from Actinomadura $\mathrm{R} 39(30 \mathrm{mM}$ Tris- $\mathrm{HCl} \mathrm{pH} 7.5+3 \mathrm{mM} \mathrm{MgCl})$. The amounts of enzyme used were such that the activities measured in the absence of antiserum necessitated $4 \mathrm{~h}$ of incubation at $37^{\circ} \mathrm{C}$ with the substrates, except for the lysozyme-releasable enzyme of Streptomyces rimosus in which case the incubation time was of $18 \mathrm{~h}$

\begin{tabular}{|c|c|c|c|c|c|c|c|}
\hline \multirow[t]{2}{*}{ Strain } & \multirow[t]{2}{*}{ Enzyme } & \multicolumn{3}{|c|}{ 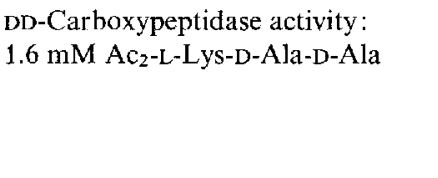 } & \multicolumn{3}{|c|}{ 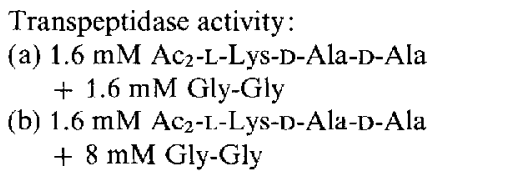 } \\
\hline & & $\begin{array}{l}\text { activity } \\
\text { in the } \\
\text { absence } \\
\text { of } \\
\text { antiserum }\end{array}$ & $\begin{array}{l}\text { antiserum } \\
\text { present } \\
\text { in } 30 \mu \mathrm{I} \\
\text { final } \\
\text { volumes }\end{array}$ & $\begin{array}{l}\text { activity } \\
\text { in the } \\
\text { presence } \\
\text { of } \\
\text { antiserum }\end{array}$ & $\begin{array}{l}\text { activity } \\
\text { in the } \\
\text { absence } \\
\text { of } \\
\text { antiserum }\end{array}$ & $\begin{array}{l}\text { antiserum } \\
\text { present } \\
\text { in } 30 \mu \mathrm{l} \\
\text { final } \\
\text { volumes }\end{array}$ & $\begin{array}{l}\text { activity } \\
\text { in the } \\
\text { presence } \\
\text { of } \\
\text { antiserum }\end{array}$ \\
\hline & & $\%$ & $\mu 1$ & $\%$ & & $\mu l$ & $\%$ \\
\hline Streptomyces R61 & exocellular & 23 & 0.05 & 3.0 & $\begin{array}{l}\text { (a) } 4 \\
\text { (b) } 10\end{array}$ & $\begin{array}{l}0.17 \\
0.17\end{array}$ & $\begin{array}{l}0.6 \\
2.9\end{array}$ \\
\hline Streptomyces R61 & $\begin{array}{l}\text { lysozyme- } \\
\text { releasable }\end{array}$ & 20 & 0.05 & 2.6 & $\begin{array}{ll}\text { (a) } & 2.14 \\
\text { (a) } & 2.25 \\
\text { (b) } & 5.47\end{array}$ & $\begin{array}{l}0.17 \\
1 \\
1\end{array}$ & $\begin{array}{l}0.6 \\
0.5 \\
1.1\end{array}$ \\
\hline Streptomyces K15 & exocellular & 22 & 1 & 15.8 & & & \\
\hline Streptomyces K15 & $\begin{array}{l}\text { lysozyme- } \\
\text { relcasable }\end{array}$ & 20 & 0.05 & 1.8 & $\begin{array}{ll}\text { (a) } & 3.35 \\
\text { (a) } 2.50 \\
\text { (b) } 6\end{array}$ & $\begin{array}{l}0.17 \\
1 \\
1\end{array}$ & $\begin{array}{l}0.5 \\
0.7 \\
1.1\end{array}$ \\
\hline Streptomyces rimosus & $\begin{array}{l}\text { lysozyme- } \\
\text { releasable }\end{array}$ & 10 & 1 & 2.5 & & & \\
\hline Streptomyces albus $\mathrm{G}$ & exocellular & 24 & 1 & 24 & & & \\
\hline Actinomadura R39 & exocellular & 23 & 1 & 23 & & & \\
\hline
\end{tabular}

and Streptomyces albus G (Table 1). The lysozymereleasable enzymes from strains $\mathrm{R} 61, \mathrm{~K} 15$ and rimosus were inhibited by $70-90 \%$ both in the DD-carboxypeptidase and the transpeptidase assays. The exocellular enzyme from strain K15 was only inhibited by about $28 \%$. This low extent of enzyme inhibition might be easily explained if one assumes that the second penicillin-binding component of $M_{\mathrm{r}} 62000$ present in the K15 enzyme preparation [1] is another DD-carboxypeptidase not related immunologically to the DD-carboxypeptidase of $M_{\mathrm{r}} 38000$.

The microscale system was modified to assay the effects of the antiserum on the membrane-bound enzymes. In this modification, membranes $(1.8 \mathrm{mg}$ protein), antiserum or control serum (dilution range: $1 / 6$ to $1 / 300$ ) were incubated together in $14 \mathrm{mM}$ phosphate buffer $\mathrm{pH} 7.5$ (final volume: $72 \mu \mathrm{l}$ ) for $1 \mathrm{~h}$ at $37^{\circ} \mathrm{C}$ and then for $18 \mathrm{~h}$ at $4{ }^{\circ} \mathrm{C}$. Samples were removed and tested for DD-carboxypeptidase and transpeptidase activities. The experimental conditions and results are given in Table 2. Other than a slight inhibition $(19 \%)$ of the membrane-bound DD-carboxypeptidase activity of strain $\mathrm{K} 15$, the antiserum had no effect on the other membrane-bound enzymes tested.

\section{DISCUSSION}

The antiserum to exocellular R61 enzyme was found to inhibit the DD-carboxypeptidase and transpeptidase activities as well as the penicillin-binding capability of the exocellular R61 enzyme. This same antiserum was also found to inhibit the exocellular and lysozyme-releasable DD-carboxypeptidases from Streptomyces R61, K15 and rimosus. This observation suggests a certain structural relatedness for these enzymes. Whether the observed antigenic cross-reactivity is due to a similarity of the active sites or other areas of the enzyme molecules warrants further study. The antiserum to exocellular R61 enzyme had no effect on the activity of the membrane-bound transpeptidases of the three strains examined. It is known that a temperature as low as $-30^{\circ} \mathrm{C}$ is required to prevent the membranes of Streptomyces R61 from performing 
Table 2. Effects of the antiserum to exocellular R6I enzyme on the DD-carboxypeptidase und transpeptidase activities of the membranes of Streptomyces $R 61, K 15$ and rimosus

DD-Carboxypeptidase activity was estimated by incubating for $20 \mathrm{~h}$ at $37^{\circ} \mathrm{C}, 25-\mu \mathrm{l}$ samples of the membrane/antiserum suspensions in

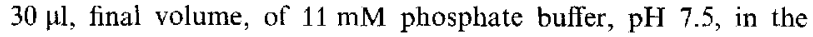
presence of $4.7 \mathrm{mM} \mathrm{Ac}$-L-Lys-D-Ala-D-Ala. Depending upon the membranes, $4-10 \%$ of the tripeptide was hydrolysed in the control samples. Transpeptidase activity was estimated by incubating for $4 \mathrm{~h}$ at $37^{\circ} \mathrm{C}$, samples of the membrane/antiserum suspensions in

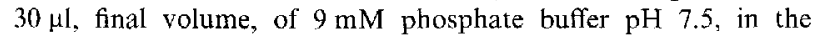
presence of $1.6 \mathrm{mM} \mathrm{Ac} \mathrm{c}_{2}$-L-Lys-D-Ala-D-Ala and $1.6 \mathrm{mM}$ Gly-Gly. The volumes of the samples used were: (1) for strain R61:2.5 $\mu \mathrm{l}$ (a), $1.25 \mu \mathrm{l}$ (b), $3 \mu \mathrm{l}$ (c); (2) for strain $\mathrm{K} 15: 10 \mu \mathrm{l}$; and (3) for strain rimosus: $2.5 \mu \mathrm{l}$ (d) and $2 \mu \mathrm{l}$ (e). Depending upon the cases, $1.5-6.2 \%$ of the tripeptide was transformed into $\mathrm{Ac}_{2}-\mathrm{L}-\mathrm{Lys}-\mathrm{D}-$ Ala-Gly-Gly in the control samples. The average value for all the residual activities in the presence of antiserum, except for the membrane-bound DD-carboxypeptidase of strain K 15 , is $104 \%$ with a standard deviation value of 10 . The average value for the K15 residual Do-carboxypeptidase activity is $81 \%$ with a standard deviation of 4

\begin{tabular}{llll}
\hline \multirow{2}{*}{$\begin{array}{l}\text { Strain } \\
\text { dilution }\end{array}$} & \multicolumn{2}{l}{\begin{tabular}{l} 
Residual activity \\
\cline { 3 - 4 }
\end{tabular}} & $\begin{array}{l}\text { } \begin{array}{l}\text { DD-carboxy- } \\
\text { peptidase }\end{array} \\
\text { trans- } \\
\text { peptidase }\end{array}$ \\
\hline \multirow{3}{*}{ \% control samples } \\
\cline { 3 - 4 } R61 & $1 / 6$ & $92-104$ & $125(\mathrm{a})-107(\mathrm{~b})$ \\
& $1 / 30$ & 102 & $91(\mathrm{c})$ \\
K15 & $1 / 300$ & & $108(\mathrm{c})$ \\
& $1 / 6$ & $79-76-81$ & $90-114$ \\
& $1 / 30$ & 86.5 & 97 \\
rimosus & $1 / 300$ & 81 & 124 \\
& $1 / 6$ & $103-104$ & $107(\mathrm{~d})$ \\
& $1 / 30$ & 93 & $111(\mathrm{e})$ \\
& $1 / 300$ & 98 & $96(\mathrm{c})$ \\
\hline
\end{tabular}

transpeptidation reactions [5]. Such a property suggests that the enzyme is deeply buried within the lipid phase of the membrane and for this reason, antigenic sites may be inaccessible to antibodies. Part of the DD-carboxypeptidase activity of the membranes of strain $\mathrm{K} 15$, however, was inhibited by the antiserum to exocellular R61 enzyme. It can thus be attributed to an enzyme which is distinct from the transpeptidase and is immunologically related to the exocellular and lysozyme-releasable enzymes.

The work was supported in part by the Fonds de la Recherche Fondamentale Collective, Brussels, Belgium and by the National Institutes of Health, Washington D.C., (contract no. 1 RO1 AI 13364-01 MBC). We also thank UCB, Brussels, Belgium, for financial support. M. N-D. and J.D. are Chargés de Recherches of the Fonds National de la Recherche Scientifique, Brussels, Belgium. J.J.P. acknowledges support (grant AI 12195) from the National Institute of Allergy and Infectious Diseases, National Institutes of Health, Bethesda, Md.

\section{REFERENCES}

1. Leyh-Bouille, M., Dusart, J., Nguyen-Distèche, M., Ghuysen, J. M., Reynolds, P. E. \& Perkins, H. R. (1977) Eur. J. Biochem. 8I, 19-28:

2. Frère, J. M., Leyh-Bouille, M., Ghuysen, J. M., Nieto, M. \& Perkins, H. R. (1976) Methods Enzymol. 45, 610-636.

3. Ghuysen, J. M. (1977). The Bacterial DD-CarboxypeptidaseTranspeptidase Enzyme System: A New Insight Into the Mode of Action of Penicillin, E. R. Squibb Lectures on Chemistry of Microbial Products (series ed. Brown, W. E.) University of Tokyo Press.

4. Ouchterlony, Ö. (1958) Prog. Allergy, 5, 1--73.

5. Dusart, J., Marquet, A., Ghuysen, J. M. \& Perkins, H. R. (1975) Eur. J. Biochem. 56, 57-65.

M. Nguyen-Distèche, J.-M. Frère, J. Dusart, M. Leyh-Bouille, and J.-M. Ghuysen *, Service de Microbiologie, Faculté de Médecine, Institut de Botanique, Université de Liège au Sart-Tilman, B-4000 Liège, Belgium

J. J. Pollock, Department of Oral Biology and Pathology, School of Dental Medicine, State University of New York at Stony Brook, Stony Brook, New York, U.S.A. 11790

V. J. Iacono, Department of Periodontics, School of Dental Medicine, State University of New York at Stony Brook, Stony Brook, New York, U.S.A. 11790

* To whom correspondence should be addressed. 